\title{
Improvement of Activity and Social Studies Learning Outcomes through Teams Game Tournament Using Crossword Puzzle
}

\author{
Ismayenti', Syafri Anwar', ${ }^{2}$ hairani ${ }^{3}$ \\ ${ }^{123}$ Universitas Negeri Padang, Padang - Indonesia, (ismayenti13@gmail.com)
}

\begin{abstract}
This research was motivated by low activity and learning outcomes of social studies sat IX.1 class in SMP Negeri 3 Sungai Geringging. Therefore it was necessary to improve learning, . The purpose of this study was to improved the activity and learning outcomes of social science through cooperative learning model, type teams game tournament by using crossword puzzle on the achievement of nineth grade students in SMP Negeri Sungai Geringging, semester 1 academic 2017/2018. The method used wasclassroom action research. The research procedure was conducted in two cycles. Each cycle consists of four stages: planning, acting, observing, and reflecting. Data collection techniques such as observation and formative tests (cognitive). Data analysis techniques used qualitative and quantitative analysis. The results was found the average percentage of the students activity in cycle 1 was $63.8 \%$, in increased to $90.5 \%$ (very active). the average score was 73.9 in cycle 1 , with percentage $65.7 \%$ or 23 students completed, the average score in cycle 279,3 with percentage $88,6 \%$ or 31 students completed
\end{abstract}

Keywords: activity, learning outcomes, cooperative learning model type teams game tournament, Crossword puzzle.

\section{Introduction}

According to Law No. 20 of 2003 article 1, point 1 of education is a conscious and planned effort to create an atmosphere of learning and learning process so that learners actively develop their potential to have spiritual power, self-development, personality, noble character, and skill which belongs to himself, society, nation and state. In the enhanced 2004 Curriculum it is also expected that the learning process should be able to create an active, creative and fun atmosphere so that students are able to develop themselves according to their environment.From the observation and direct experience of the researcher, the percentage of students who active in social studies study was very low, and the active students for each meeting are almost the same students. The condition of inactivity of these students, have an impact on the low learning outcomes social studies students. Low learning outcomes can be seen from the results of repetition achieved by students. Daily test value of them majority can not reach the Minimal mastery criteria that is value 79 , so it did not reach classical completeness. While the learning activities can be said to succeed if $85 \%$ students in the class reached the Minimal mastery criteria. Of the five rombels of IX class students in SMP Negeri 3 Sungai 
Geringging, the outcomes of social studies learning students of IX.1, the students of IX.1 class were the class with the lowest learning o utcomes. The low learning outcomes of IX.1class students of SMP Negeri 3 Sungai Geringging can be seen from the low value of daily test value 1 (first semester) for Social Studies subjects, as shown in the following table.

Table \#1 (Daily test value 1 Class Social Studies subject IX grade Semester I SMPN 3 Sungai Geringging Academic 2017/2018)

\begin{tabular}{ccccccc}
\hline & & & & \multicolumn{2}{c}{$\%$ Completed } \\
\cline { 6 - 7 } Rombel & Number of & Average & Student & Uncom- \\
Class IX & $\begin{array}{c}\text { Students Per } \\
\text { Rombel }\end{array}$ & $\begin{array}{c}\text { Score } \\
\text { CH 1 }\end{array}$ & $\begin{array}{c}\text { Com- } \\
\text { pleted }\end{array}$ & $\begin{array}{c}\text { plicated } \\
\text { Students }\end{array}$ & Com-pleted & Uncom- \\
IX.1 & 35 & 51,6 & 14 & 21 & 40,0 & plicated \\
IX.2 & 34 & 60,0 & 18 & 16 & 52,9 & 47,1 \\
IX.3 & 31 & 63,3 & 20 & 11 & 64,5 & 35,5 \\
IX.4 & 32 & 59,5 & 15 & 17 & 46,9 & 53,1 \\
IX.5 & 32 & 60,6 & 16 & 16 & 50,0 & 50,0 \\
\hline
\end{tabular}

During this time in the learning activities of teachers often use lecture methods interspersed with question and answer, and discussion, but only a small percentage of students who actively involved in learning activities, the percentage of students activity was very low. Discussion methods were also not be able to activate all of the students. Junior high school students who still in the transition from children to teenagers, still missed playing in learning. This situation turned out to be one of the facts that affect the low learning outcomes of students.To improve the activity and learning outcomes of social studies students try to apply cooperative learning model type Teams Game Tournament using crossword puzzle. This model is believed be able to increase student learning activities and learning outcomes. Based on classroom action research conducted by Zulfahmi in class VIII SMPN 16 Banda Aceh, application of Teams Game Tournament model using Crossword Puzzle can improve student learning outcomes. Classic completeness has increased, the first cycle $50 \%$, in the second cycle increased to $70 \%$, and in the third cycle to $90 \%$. Based on the results of this study, researchers interested in conducting research on "Increasing Activities and Results Student Social Studies Through Application Cooperative Learning Model Type Teams Game Tournament Using Crossword Puzzle In IX.1 class students of SMPN 3 Sungai Geringging".

\section{Method}

The subject for the study was conducted in IX.1 class of SMP Negeri 3 Sungai Geringging for 4 weeks starting from 01 November to 22 November 2017. Research sample was IX.1 class students. research model was cooperative learning through Teams Game Tournamaent by using crossword puzzle. The method used was classroom action research. The research procedure was conducted in two cycles. Each cycle consists of four stages: planning, acting, observing, and reflecting. To obtain research data used observation techniques and formative tests (cognitive). Data analysis techniques using qualitative and quantitative analysis.

1. Activity analysisThe data sheet of observation activity of students will be analyzed by quantitative means in percentage. To see how much percentage of students learning activity increase to see each indicator with the following conditions:

$$
\begin{array}{|c|}
\hline \mathrm{P}=\mathrm{F} \times 100 \% \\
\mathrm{~N}
\end{array}
$$


2. Analysis of students learning outcomes To know the cognitive ability of students in solving the problem is to calculate the average value and mastery learning. The formula used is:

a. Calculate the average value of learning outcomes

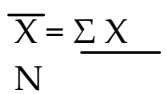

\section{Keterangan:}

$\bar{X}=$ Average test result

$\Sigma \mathrm{X}=$ Total test scores all learners

$\mathrm{N}=$ the number of participants being examined who follow the exam.

b. Calculating the mastery of classical learning

$\mathrm{P}=\Sigma \mathrm{n} 1 \times 100 \% \Sigma \mathrm{n}$

Description:

$\mathrm{P}=$ Classical learning completeness value

$\Sigma \mathrm{n} 1=$ Number of students learn complete

$\Sigma \mathrm{n}=$ total number of participants students.

c. Success Indicators

Data obtained from tests are analyzed to see the achievement of the Minimal Mastery Criteria. Students can be said to have reached MEC if it has reached value 79. In this study expected number of participants who have reached Minimal Mastery Criteria is $>85 \%$. Studentsare said to be complete if they get value> MEC (Depdiknas, 2004). Students are said to reach Mastery Minimal Criteria if NI> 79\% To reach the percentage of many students who have reached used formula:

$\mathrm{NT}=\mathrm{ST} \times 100 \% \mathrm{~N}$

Description:

$\mathrm{NT}=$ percentage of number of students reaching

$\mathrm{ST}=$ Number of students who reach

$\mathrm{N}=$ Total of participants students in the classroom Furthermore it is said that the class has succeeded if NT> $85 \%$

\section{Results and Discussion}

\section{Students activities}

According to hamzah (2012:77), active learning in the learning process is students are expected to activelly angage in learning activities to think interact, do, to try, find a new concept or produce a work. Similar to what is proposed by Hamzah, Mulyasa (2006:241) suggest, partisipative learning ia defined as the involvement of learners in the planning, implementation, and evaluation of learning. Based on the statement above if increased learning outcomes in social science using crossword puzzle was effective for students activities.

Based on expert opinion about active, creative, and participative learning, the researher applies cooperative learning model type Teams Game Tournament by using croosword puzzle which succeeded in increasing the activity and result of students learning. Percentage of students activity in learning on cycle 1 and cycle 2 were summarized in figure 1 below. 


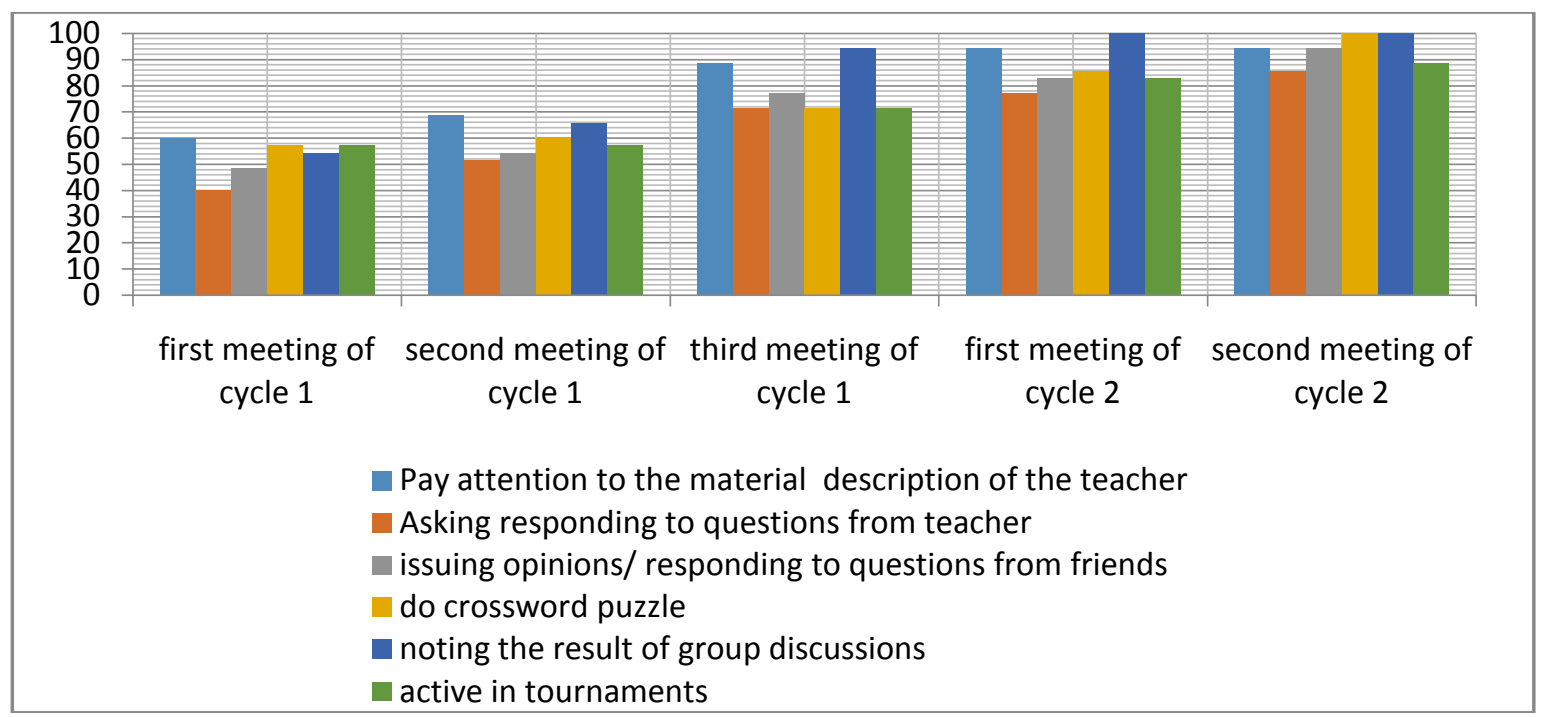

Figure \# 1(Graph of Outcome learning social science students).

The students activity on Figure 1 shows the increased of learners activities in each activity type from activity to pay attention to the material description of teacher, ask / respond to questions from teacher, expressing opinions/ responding to friends' questions, doing crossword puzzle, recording group discussion results, and being active in tournaments. Increased activity of these students occurs due to the application of cooperative learning model type Teams Game Tournament using crossword puzzle applied by researchers. Where researchers has never applied this model before. Enhancement of the students activity, for each activity the students attention to the material description of the teacher increased for each meeting in cycle 1 . The first meeting of cycle 1 was only $60 \%$, then increased to $68.6 \%$ at the second meeting, and became $88.6 \%$ in the third meeting. At the first meeting of cycle 2 it increased to $94.3 \%$, and in the second meeting remained at $94.3 \%$, with the percentage increased in activity between cycle 1 and cycle 2 of $21.9 \%$. Activity raising/ responding to questions from teachers increased from $40 \%$ in the first meeting of cycle 1 to $51.4 \%$ at the second meeting and to $71.4 \%$ at the third meeting. In the 2-digit cycle it increased to $77.1 \%$ in the first meeting and increased to $85.7 \%$ at the second meeting, with the percentage increased between cycle 1 and cycle 2 of $27.1 \%$. Disclosure activities/ responses to friends' questions in the discussion also increased from $48.5 \%$ in the first meeting of cycle 1, increased to $54.3 \%$ at the second meeting and to $77.1 \%$ at the third meeting. In cycle 2 it increased again to $82.9 \%$ at the first meeting and increased to $94.3 \%$ at the second meeting, with the percentage increase between cycle 1 and cycle 2 of $28.6 \%$. Activities on Crossword puzzle have improved from $57.1 \%$ at the first meeting of cycle 1 and $60 \%$ at the second meeting and $71.4 \%$ at the third meeting. Cycle 2 also increased to $85.7 \%$ at the first meeting and increased again to $100 \%$ at the second meeting, with the percentage increased between cycle 1 and cycle 2 of $30.1 \%$. In the activity of recording the results of group discussions increased from $54.3 \%$ in the first meeting of cycle 1 to $65.7 \%$ at the second meeting and increased to $94.3 \%$ at the third meeting. In cycle 2 for both meetings increased to $100 \%$, with the percentage increase from cycle 1 to cycle 2 of $28.6 \%$. Activity attempts actively playing in completing the given tournaments also increased significantly from $57.1 \%$ in the first meeting and second cycle 1 increased to $71.4 \%$ at the third meeting. In cycle 2 it increased to $82.9 \%$ at the first meeting and continued to increase to $88.6 \%$ at the second meeting, with the percentage increased between cycle 1 and cycle 2 of $23.9 \%$.

\section{Outcomes of learning social studies for the students}

The findings of the study showed an increase in learning outcomes of students after the study. In general the improvement of learning outcomes of learners can be seen in Figure 2. below. 


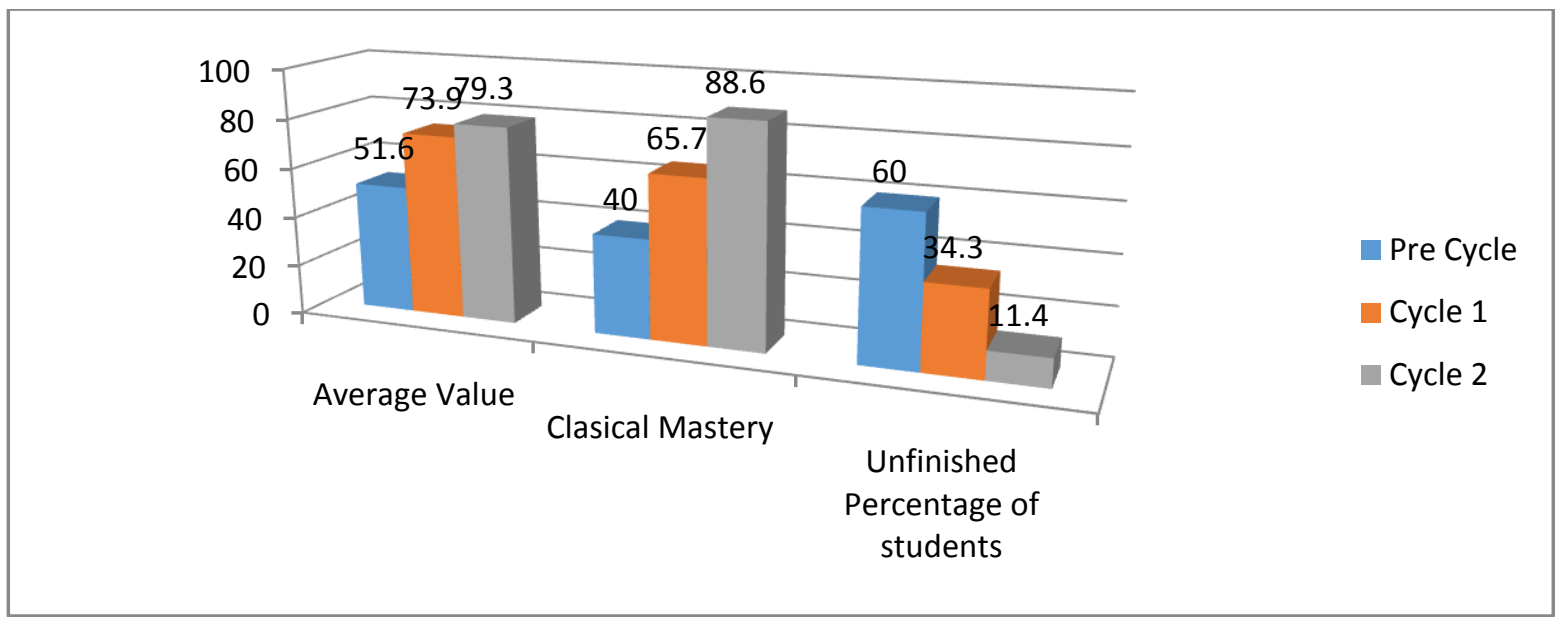

Figure 2. Graph of student learning outcomes

The learning results show that the average value of the individual completeness increased from cycle 1 to cycle 2. In detail the increase can be seen in Figure 3. below.

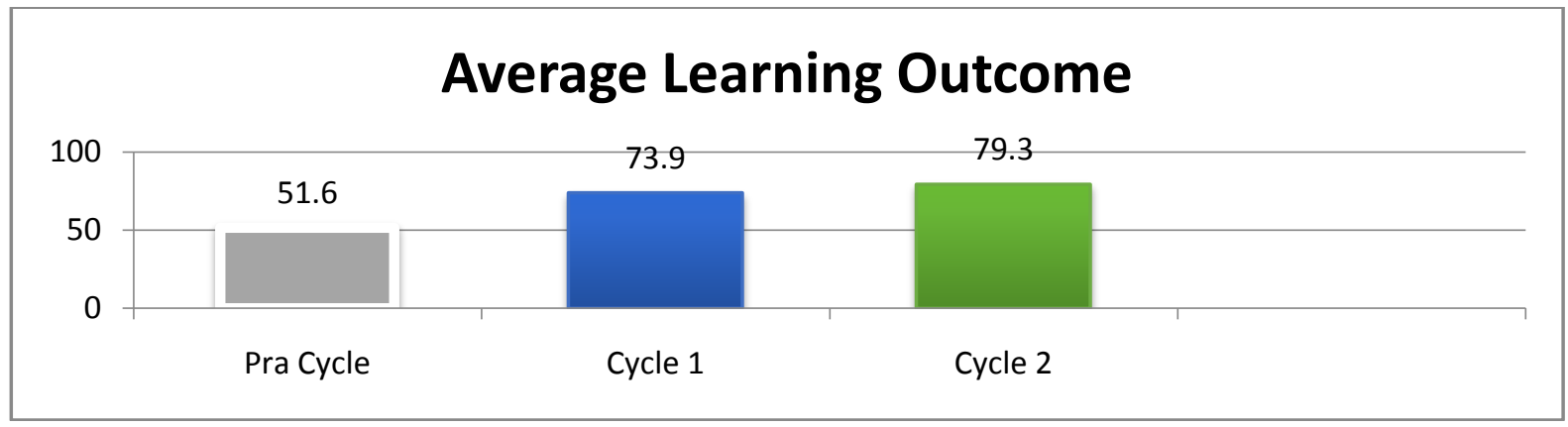

Figure 3. Graph of average learning outcomes of students

Based on Figure 3. above there is an increase in the average score of learners from 51.6 on pra cycle, increased to 73.9 in cycle 1 , and then increased to 79.3 on cycle 2 . The increase also occurs in the classical completeness of learners from $40 \%$ in pra cycle increased to $65.7 \%$ in cycle 1 , and continued to increase in cycle 2 to $88.6 \%$. Improvement of the classical completeness of learning outcomes of these learners can be seen in Figure 4. below.

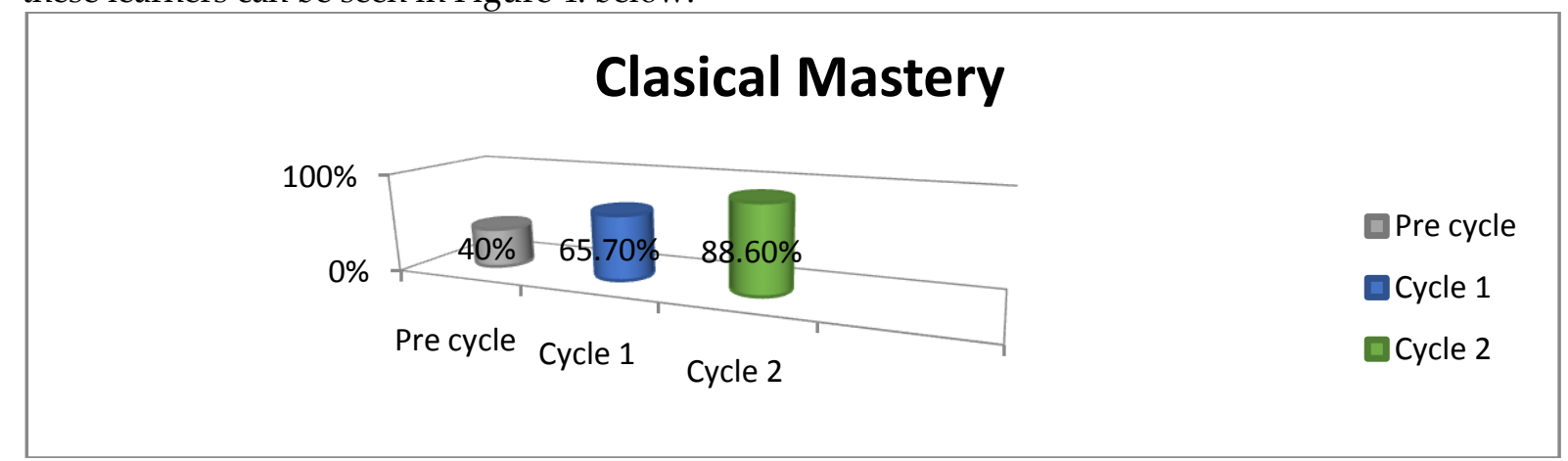

Figure 4. Graphic mastery of classical students

Improvement of classical completeness occurs along with the increase of individual students mastery. The number of individual students who completed the pre cycle only 14 students, in cycle 1 increased to 23 students, and in cycle 2 increased again to 31 students. The opposite happens to uncompleted learners. Decrease in the number of students who did not complete from pra cycle amounted to 21 students, down to 12 students in cycle 1 and added down in cycle 2 that is only 4 
students only. In detail the picture of the mastery of individual students can be seen from Figure 5. below.

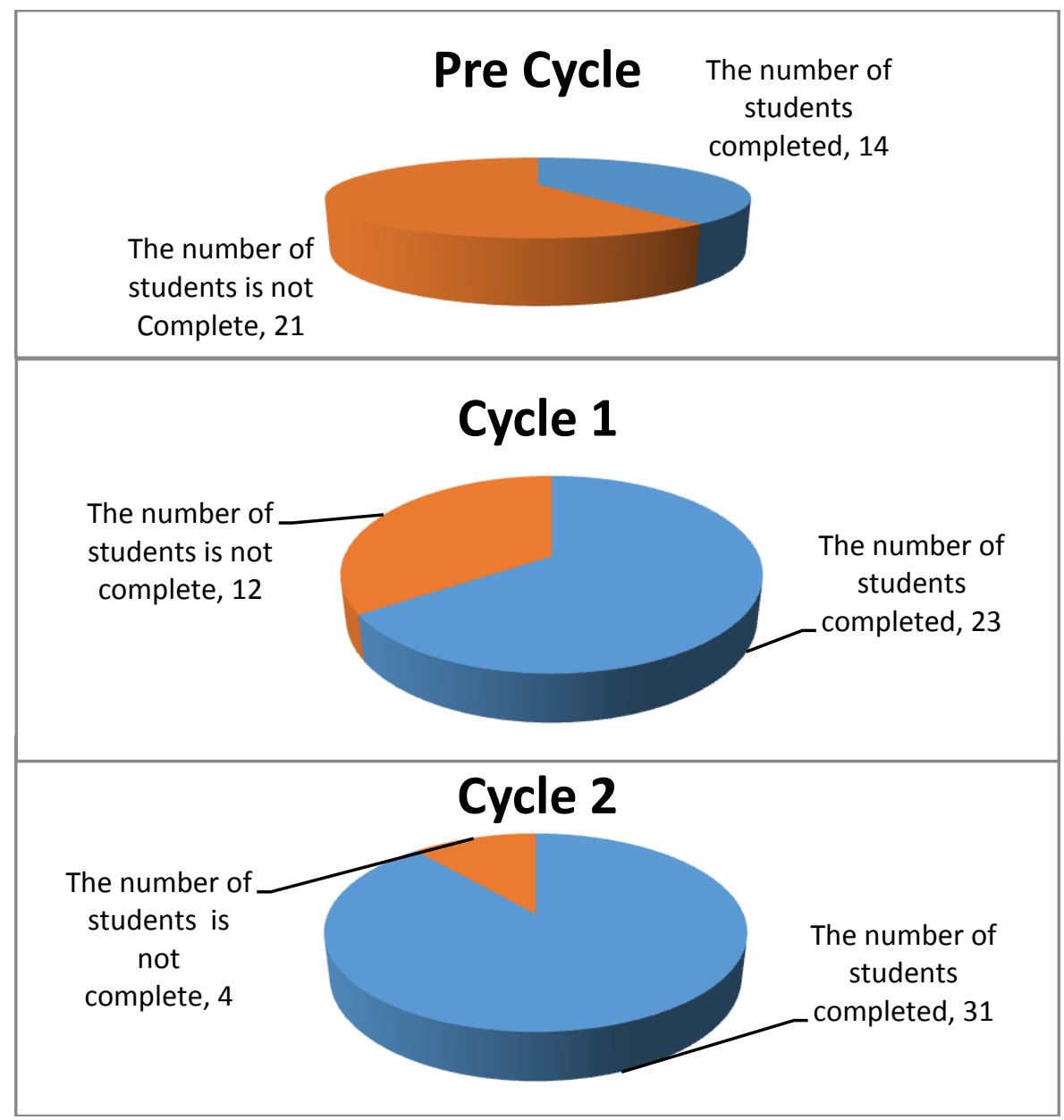

Figure 5. Graphs mastery of individual students

There is three implications in this research such as outcomes learning implication means there was increased activities and outcomes of learning in social studies subject, through cooperative learning Teams Game Tournament by using crossword puzzle, second theoretical implication is the theoretical implication of this research are to increase the sciece of classroom action research, so as to encourage other educators and researcher to conduct similar researh to improve learning outcomes of this study can also be a reference material to develope active, creative and fun learning, so it can be used as material consideration for the teachers to apply different learning model on social scence subject aswell as other subject. The teacher can also better understand the needs and condition of students in learning os as to create at appropriate learning situation and appropriate for students. Third practical implicationof this research the finding of positive towards improvement in the quality of social science learning. This research open the insights of students and teacher to the model of learning, especially in applying cooperative learning model type Teams Game Tounament by using crossword puzzle.

The learning can run smoothly requires preparation of mature teachers, the ability to manage the class, the ability to understand and apply the model of learning appropriately to get maximum result. For students are expected to take the lesson seriously as to achieve optimal learning objectives 


\section{Conclusions}

Based on the outcomes and discussions described above can be concluded that the activities and learning outcomes of the students IX.1 class in SMP Negeri 3 Sungai Geringging Semester I Academic 2017 / 2018 applied cooperative learning model type TGT using crossword puzzle media has significant improvement from pre cycle 1 to post cycle 2 . Each activity more attention to material description from teacher increased equal to $21.9 \%$, activity of asking / responding questions from teacher increased equal to $27.1 \%$, the activity of expressing opinions or responding to questions from the teacher increased by $28.6 \%$, the activity on crossword puzzle increased by $30.1 \%$, the activity recorded the results of the group discussion increased by $28.6 \%$, and actively trying to play in solving the tournament problem granted increased by $23.9 \%$. While for the average learning outcomes from pre cycle to cycle 1 increased by $22.3 \%$, and $5.4 \%$ from cycle to cycle 2 . For classical completeness from pre cycle to cycle 1 increased by $25.7 \%$, and by $22.9 \%$ from cycle 1 to cycle 2 . Based on the results of research on the application of cooperative learning model type Teams Game Tournament by using crossword puzzle media to smoothly required preparation of mature teachers, the ability to managed the class, the ability to understand and apply the model of learning appropriately in order to achieve the maximum result. For students was expected to follow the learning activities seriously will achieved the learning objectives with optimal.

\section{Acknowledgments}

On the process of this research, researcher get help, direction and guidance, from various parties. On this occation the researcher would like to thanks to the guidance concelors are Honorable Mr. Prof. Dr Syafri Anwar, M.Pd. , Honorable Mr. Dr. Khairani, M.Pd. and the researcher also would like to thanks to the contributors Mr. Dr. Helmi Hasan, M.Pd., Mr. Dr. Erianjoni, M.Si. , Mr. Dr. Darmasnyah, M.Pd, next thanks to observer Mr. Zamdrawasih, S.E. As well as the parties who helped in the research and writing of this article.

\section{References}

Arikunto, Suharsimi dkk (2008). Penelitian Tindakan Kelas. Jakarta: Bumi Aksara.

Arikunto, Suharsimi dkk(2008). Dasar-dasar Evaluasi Pendidikan. Jakarta: BumiAksara.

Dewi, Agustin Kumala, dkk. 2016. Penerapan Model Pembelajaran Teams Games Tournaments (TGT) disertai Video Compact Disk (VCD) dan Teka Teki Silang (TTS) untuk Meningkatkan Minat dan Prestasi Belajar Kimia Pada Materi Konsep Materi dan Perubahannya Kelas X SMK Muhammadiyah 2 Sragen. Jurnal Pendidikan Kimia FKIP UNS, 5(3)

Mudjiono, Dimyati(2010). Belajar dan Pembelajaran. Jakarta: PT. Rineka Cipta.

Djamarah, (2008). Psikologi Belajar. Jakarta: PT. Rineka Cipta.

Ervawati(2016). Upaya Peningkatan Aktivitas Belajar Geografi Melalui Teka Teki Silang Pada Siswa Kelas XI 1 SMA Negeri 1 Lubuk BasungJurnal Pendidikan dan Keluarga,8 (2):

Fajri, Luluk, dkk(2012).Upaya Peningkatan Proses Hasil Belajar Kimia materi Koloid Melalui Pembelajaran Kooperatif Tipe Teams Games Tournament (TGT) dilengkapi dengan Teka Teki Silang (TTS) Bagi Siswa Kelas XI IPA 4 SMA Negeri 2 Boyolali Pada Semester Genap Tahun Pembelajaran 2011/ 2012JPK, Jurnal Pendidikan Kimia, 1 (1): 89-96.

Hamalik, Oemar(2010). Kurikulum dan Pembelajaran. Jakarta: Bumi Aksara.

Huda, Miftahul(2014). Model-model Pengajaran dan Pembelajaran. Isu-isu Metodis dan Paradigmatis. Yogyakarta: Pustaka Pelajar

Isjoni(2010). Pembelajaran Kooperatif. Yogyakarta: Pustaka Pelajar. 
Kinanti, Putri Wahyu,dkk. (2013). Penerapan Model Pembelajaran Teams Games Tournament (TGT) Dengan Permainan Teka Teki Silang (TTS) Untuk Meningkatkan Motivasi dan Hasil Belajar Biologi (Pokok bahasan Ekosistem Di SMP Negeri 14 Jember Tahun Pelajaran 2012/ 2013). Pancaran Pendidikan, Jurnal UNEJ, 3 (1): 27-36.

Mulyasa,E. (2003). Kurikulum Berbasis Kompetensi, Konsep Karakteristik dan Implementasi. Bandung: Remaja Rosdakarya

Mursilah. (2017).Penerapan Metode Pembelajaran Crossword Puzzle dalam Meningkatkan Hasil Belajar IPS kelas XII SMK Nurul Huda Sukaraja. Jurnal Ilmiah Pendidikan dan Ekonomi, 1 (1): 37 47.

Nasution, S. (2000). Azaz-azas Mengajar. Bandung: Jemnas

Ngalim Purwanto. (2004). Prinsip-prinsip dan Teknik Evaluasi Pengajaran.

Bandung: PT Remaja Rosdakarya.

Nurdianawati, Nita Dewi. (2011). Peningkatan Hasil Belajar Biologi Pokok Bahasan Organisasi Kehidupan Melalui Strategi Pembelajaran Tipe Crossword Puzzle (Teka Teki Silang) Pada Siswa Kelas VII C SMP Negeri 1 Gatak Sukoharjo Tahun Ajaran 2010/ 2011. Eprints, UMS.

Nurhayati, Liyana, dkk. (2013). Peningkatan Kreativitas dan Prestasi Belajar Pada Materi Minyak Bumi Melalui Penerapan Model Pembelajaran Problem Based Learning (PBL) Dengan Media Crossword.Jurnal FKIP UNS, 2 (4)

Pasunsungan, Oktaviani, dkk(2013). "Peningkatan Aktivitas Belajar IPS dengan Metode Teka Teki Silang di SDN 05 Beruak Sanggau". Jurnal Pendidikan dan Pembelajaran, UNTAN, 2 (3)

Pratama, Endhika Haries, dkk. (2014). Peningkatan Aktivitas dan Hasil Belajar Biologi Menggunakan Model Pembelajaran Teams Games Tournament (TGT) disertai TTS Pada Siswa Kelas VII SMP Mitra Jember Semester genap Tahun Pelajaran 2012/ 2013. Pancaran, 3 (2): 93-102

Sani, Ridwan Abdullah. (2014). Inovasi Pembelajaran. Jakarta: Bumi Aksara

Sanjaya, Wina. (2006).Pembelajaran dalam Implementasi Kurikulum Berbasis Kompetensi. Jakarta: Kencana Prenada Media Group

Sanjaya, Wina. (2008). Strategi Pembelajaran Berorientasi Standar Proses Pendidikan. Jakarta: Kencana

Saputri, Agatha dan Sukirno. (2016). Penerapan Metode Active Knowledge Sharing Berbantu Media Teka Teki Silang (TTS) untuk Meningkatkan Aktivitas Belajar dalam Mata Pelajaran Akuntansi. Jurnal Pendidikan Akuntansi Indonesia, XIV (1) : 10-24

Sardiman. (2009). Interaksi dan Motivasi Belajar Mengajar. Jakarta: RajawaliPers

Schunk, Dale H. (2008). Motivation in Education: Theory, Research, and Applications. New Jersey: Pearson Merrill Prentice Hall.

Septianingrum, Resti , dkk. (2014). Penerapan Metode Number Heads Together (NHT) disertai Media Teka Teki Silang untuk Meningkatkan Kemampuan Memori dan Prestasi Belajar Kimia Pada Materi Sistem Koloid Kelas XI IPA 2 SMA Negeri 2 Karanganyar Tahun Pelajaran 2012/ 2013. Jurnal FKIP UNS, 3 (1)

Silberman, Melvin L. (2011). Active Learning 101 Cara Belajar Siswa Aktif. Bandung: Nuansa

Suciyanto, Andi Dwi. (2013). Upaya Meningkatkan Minat dan Hasil belajar IPS Menggunakan Metode Teka Teki Silang di Kelas VIII C SMP Negeri 2 Prambanan.

Sudjana, Nana. (2011). Penilaian Hasil Proses Belajar Mengajar. Bandung: PT.Remaja Rosdakarya Offset.

Sugianto, Dedi. (2017). Peningkatan Hasil Belajar IPS Pada kelas VIII C SMP Negeri 1 Ciasem Melalui Media Pembelajaran Teka Teki Silang (TTS). Jurnal Edukasi (Ekonomi, Pendidkan, dan Akuntansi), 5 (1)

Sugiyono. (2008).Metode Penelitian Kuantitatif, Kualitatif dan R \& D. Bandung:Alfabeta.

Supardi. (2011). Dasar-dasar Ilmu Sosial. Yogyakarta: Ombak

Suyadi. (2013). Strategi Pembelajaran Pendidikan Karakter. Bandung: PT Remaja Rosdakarya

Suyatno. (2009). Menjelajah Pembelajaran Inovatif. Sidoarjo: Masmedia Buana Pustaka

UU No. 20 tahun 2003 tentang Sistem Pendidikan Nasional. 
Yuliana Dewi Karina, Haryono Haryono, dan Sri Retno Dwi Ariani. (2014). Penerapan Model Teams Games Tournament (TGT) Dilengkapi Teka Teki Silang dan Kartu Untuk Meningkatkan Aktivitas dan Prestasi Belajar Pada Materi Koloid Kelas XI IPA 1 SMA Negeri 1 Banyudono Tahun Pelajaran 2013/2014. Karina. Jurnal Pendidikan Kimia FKIP UNS, 3 (3)

Yusuf, Nur Hayati. (2005). Media Pengajaran. Surabaya: Dakwah Digital Press

Zaini, Hisyam dkk. (2008). Strategi Pembelajaran Aktif. Yogyakarta: Pustaka Insan Madani

Zulfahmi, dkk. (2017). Penerapan Model Pembelajaran Kooperatif Tipe Teams Games Tournament Dengan Media Teka Teki Silang untuk Meningkatkan Hasil Belajar IPS Terpadu siswa Kelas VIII SMPN 16 Banda Aceh. Jurnal Ilmiah Mahasiswa Pendidikan Geografi, 2 (3): 